\section{日本臨床外科学会愛知県支部抄録 (第50回愛知臨床外科学会)}

日時：2018年 7 月16日（月）

会場：愛知県医師会館

会長：豊川市民病院 西田 勉

\begin{abstract}
A1 術前に画像診断し得た横行結腸間膜裂孔ヘルニアの 1
例

豊橋医療センター外科

青木康太朗、二宮 豪、安藤雅規、稲岡健一、伊藤 武、山下克 也、佐藤 健、市原 透

症例は77歳女性で、糖尿病の既往があり、嘔吐、腹痛を主訴に当 院外来を受診した。腹部 CT 検查にて、横行結腸の頭側、胃の背側、 膵臓の腹側の網囊䏶を占める様に、トライツ䩲帯から連続するよ うに空腸が輪状に存在し、拡張していた。この空腸の腸間膜は収 束像を伴っていた。中結腸動脈の左側から後腹膜方向に脱出する 内ヘルニアを疑った。この位置から空腸が網囊方向へ脱出するに は横行結腸間膜を介するため、横行結腸間膜裂孔へルニアと画像 診断した。開腹すると、術前診断に相違なく、横行結腸間膜裂孔 ヘルニアであった。腸管の虚血は認めなかった。横行結腸間膜裂 孔ヘルニアは術前診断率が低い（10\%未満）とされているが、 MDCTの普及や解剖の理解により術前診断可能と考えられた。 文献的考察を加え報告する。
\end{abstract}

A2 術前診断し得た子宮広間膜裂孔へルニアの一例

名古屋第二赤十字病院一般消化器外科

小林達矢、坂本英至、法水信治、新宮優二、尾辻英彦、山内康平、 中村勇人、米川佳彦、西村廣大、村田悠記、河野秀俊、村山未佳、 伊佐治博章

症例は69歳女性。既往に 2 回の開腹歴がある。心窝部痛を主訴に 救急外来を受診。CT検查にて子宮の右側に小腸の caliber change と背側にclosed loopを認めた。子宮広間膜裂孔ヘルニア を疑い緊急開腹術を施行した。右子宮広間膜に小腸が陥入して口 側腸管の拡張を認めた陥入小腸は約 $10 \mathrm{~cm}$ であり容易に還納可能 であった。腸管壊死所見なくへルニア門を縫合閉鎖し手術終了し た。術後経過は良好で術後10日目に退院となった。子宮広間膜裂 孔ヘルニアは、子宮広間膜の欠損による異常裂孔をへルニア門と した内へルニアである。今回、術前にCTで子宮広間膜裂孔へル ニアの診断に至った一例を経験したので報告する。
A3 腸回転異常を伴った右傍十二指腸ヘルニアの 1 例 中野胃腸病院外科

加藤 瑛、神谷賢吾、安藤拓也、深尾俊一、中野浩一郎、齋藤慎 一郎、前田頼佑、伊藤 寛

症例は92歳男性。腹部手術歴なし。下腹部痛を主訴に受診。腹部造 影CTにて内へルニアによる絞扼性イレウスの診断となり、同日緊 急手術を行った。術中所見では空腸起始部右側に約 2 横指のヘルニ ア門を認め、右側結腸間膜後面に広範囲の小腸が陥入していた。へ ルニア囊外の小腸がヘルニア門で絞扼され虚血壊死に陥っていた。 Treitz 䩗帯は認めず、腸回転異常に伴う右傍十二指腸へルニアと診 断した。ヘルニア囊に陥入した腸管を引き出して腸管の絞扼を解除 した後に、約 $82 \mathrm{~cm}$ の壞死腸管を切除しへルニア門を縫合閉鎖した。 術後一時的にせん妄を認めたがその後特に問題なく経過し術後第2 1 日目に退院となった。腸回転異常を伴った右傍十二指腸へルニアの 1 例を経過したので文献的考察を加えて報告する。

A4 腹腔鏡手術にて修復したMorgagni孔ヘルニアの 1 例 名古屋掖済会病院外科

日比野貴文、長谷部圭史、米山文彦、木村圭子、加藤祐一郎、山 口直哉、向井俊貴、秋田由美子、尾入保彰、福井史弥、山内悠司、 杉田洋之、西野真史、加藤真司、河野 弘

症例は76歳女性。心窩部痛を主訴に来院した。腹部造影 CT 検查 にて横行結腸の右胸腔への脱出を認め、Morgagni孔ヘルニアと 診断した。準緊急にて腹脉鏡下にヘルニア修復術を施行した。気 腹すると大網のみの脱出を認めたので、大網を還納した。ヘルニ ア門は大きく、直接縫合では縫縮が困難と考えられたため、ステ ープラーを用いメッシュで固定修復した。経過良好であり、術後 5 日目に退院した。もともとあった便秘も改善した。Morgagni 孔へルニアはまれであり、若干の文献的考察を加えて報告する。

A5 腹胿鏡下修復術を行ったupside down stomachを伴う 巨大食道裂孔ヘルニアの一例

豊川市民病院外科

阪本翔子、堅田武保、植松 宏、西土 徹、齋藤正樹、青山佳永、 柴田孝弥、彦坂 雄、三田圭子、柴田直史、寺西 太、柄松章司、 西田 勉

症例は77歳女性。主訴は、食後上腹部不快感と嘔吐。胸部X線検 查にて横隔膜上に異常ガス像を認めた。上部消化管内視鏡検査で は、胃の変形と高度の逆流性食道炎を認めた。上部消化管造影検 查・胸部 CT 検査では巨大食道裂孔ヘルニアを認め、縦隔内に全 胃・横行結腸の一部が脱出しており、upside down stomachを呈 していた。腹腔鏡下に胃・横行結腸の還納、食道裂孔縫縮、メッ シュ留置、噴門形成を施行した。術後は再発もなく経過良好であ る。現在食道裂孔へルニアに対する腹䏶鏡下手術が普及してきて いるが、 upside down stomachに対する腹腥鏡下手術の報告は未 だ少ない。今回我々は腹脘鏡下修復術を施行した一例を経験した ので、文献的考察を加えて報告する。

\section{A6 水疮性類天疮瘡に合併した食道癌の一例}

名古屋第一赤十字病院一般消化器外科

中島 悠、湯浅典博、竹内英司、後藤康友、三宅秀夫、永井英雅、 吉岡裕一郎、奥野正隆、宮田完志

水疮性類天疮瘡は表皮下水疮を特徵とする自己免疫疾患の 1 つで あるが、内臓悪性疾患との合併がしばしば報告されている。症例 は73歳男性で2017年 5 月、全身掻痒感を主訴に近医を受診した。 
水疮と紅皮症を認め、生検で表皮下水疮と蛍光抗体法で表皮基底 膜部へのC 3 沈着を認めたため、水疮性類天疮瘡と診断された。 ステロイドが投与されたが11月、胸痛と嚥下困難を契機に、胸部 下部食道の水疮性類天疮瘡による扁平上皮下囊胞と診断された。 その後、再度の内視鏡検查で胸部中部食道に不整な平坦隆起型病 変を認め、食道癌と診断されたため食道亜全摘を施行した。病理 組織学的に扁平上皮癌、 $0-$ II $\mathrm{c}$ 型、 $2.5 \times 4 \mathrm{~cm} 、 \mathrm{pT} 1 \mathrm{bN} 0 \mathrm{M} 0$ 、 Stage I であった。

A7 食道癌EMR後の噴門部リンパ節再発に対し salvage 手術を施行した 1 例

大垣市民病院外科

加藤大幾、金岡祐次、原田 徹、亀井桂太郎、前田敦行、高山祐 一、深見保之、高橋崇真、宇治誠人、川勝章司、三品拓也、伊藤 喜介、岡本和浩、田中祐介、手嶋浩也

症例は74歳男性。主訴はつかえ感。胃癌に対し20年前に幽門側胃 切除術、早期食道癌に対し 7 年前にEMR、3 年前に ESD の 既往 がある。CTで噴門部に $34 \mathrm{~mm}$ 大の低吸収腫瘤を認め、PET-CT で同部位への異常集積を認めた。血液検查でSCC $6.3 \mathrm{ng} / \mathrm{ml}$ と上 昇を認め、食道癌の噴門部リンパ節再発と診断し salvage 手術を 施行した。腫瘍は肝外側区、残胃、横隔膜への浸潤を認め、合併 切除した。病理組織検査は扁平上皮癌で食道癌のリンパ節転移と 診断した。食道癌内視鏡治療後のリンパ節再発に対して、salvage 手術は治療選択肢の一つに考えられる。

A8 腸間膜腫瘍との鑑別に苦慮し、病理学的にc-kit、 CD34共に陰性を示した胃GISTの 1 例

公立西知多総合病院外科

岩清水寿徳、青野景也、生田宏次、小川明男、渡邊哲也、服部正 興、平田明裕、山口貴之、野尻 基、浅野昌彦

症例は74歳女性。腹部腫瘤の精查目的に近医より当院紹介となっ た。造影 CTで腹部正中から右側に胃体下部と接する境界明瞭な $15 \mathrm{~cm}$ 大の囊胞性巨大腫瘤を認めた。上部消化管内視鏡では胃角 部から胃前庭部にかけて外部からの圧排所見を認めた。腸間膜腫 瘍の診断で待期的に手術を施行した。開腹すると腫瘍は胃前壁か ら体外性発育した腫瘍であったので、胃を部分切除して腫瘍を摘 出した。病理組織学的には、胃壁固有筋層からの発生が示唆され、 楕円形の核を持つ紡鍾形細胞が束状に増生していた。免疫染色で は、CD34 (-)、c-kit (-)、S100 (-)、 $\beta$ catenin (-)、 desmin (-)、 aSMA (+/-)、Mib- $1 \quad(<1 \%) 、$ DOG $1 \quad(+) 、$ nestin $(+)$ を 示し、c-kit陰性の GIST と診断した。今回はGISTの中でも比較 的まれな c-kit、CD34共に陰性の胃GISTを経験したので、若干 の文献的考察を加えて報告する

\section{A9 神経線維腫症 1 型に合併した胃GIST の 1 例 蒲郡市民病院外科 \\ 加古智弘、杉浦弘典、藤井善章、佐藤幹則、中村善則} 症例は69歳女性。以前より神経線維腫症 1 型と診断されていた。 平成30年 4 月上旬、嘔吐、下痢、腹痛を主訴に救急外来受診。左 季肋部に圧痛を認め、採血検查及び腹部造影 CT 検查を施行。 $\mathrm{WBC} 23,900 / \mu \mathrm{l} 、 \mathrm{CRP} 0.18 \mathrm{mg} / \mathrm{dL}$ と炎症反応の上昇を認め、胃 背側に直径 $7 \mathrm{~cm}$ 超の造影効果不均一の腫瘤及び腹水の貯留を認 めた。胃GISTの疑いで精查入院中に著明な貧血の進行を認め、 腹腔内出血疑いで緊急胃部分切除術を施行した。術中所見では手 拳大の腫瘤が胃下部後壁より発生しており、網囊内に存在してい
た。腫瘍からは出血を認めた。術後経過は良好であり術後 8 病日 で退院となった。病理検査では腫瘍はGIST と診断した。CKIT/CD34陽性、MIB-1 Index10-20\%の高リスク群であった。 神経線維腫症 1 型に合併した胃 GISTに関して、文献的考察を加 えて報告する。

A10 切除可能進行胃癌における術前Systemic Inflammation Scoreの短期および長期術後成績との関連性

名古屋大学大学院医学系研究科消化器外科学

佐藤 敏、神田光郎、田中千恵、小林大介、園原史訓、末永雅也、 高見秀樹、服部憲史、林 真路、山田 豪、中山吾郎、小池聖彦、 藤原道隆、小寺泰弘

血清アルブミン值と単球-リンパ球数比で算出するSystemic Inflammation Score（SIS）は、栄養状態と全身炎症反応を統合的 に反映する指標である。今回我々は、切除可能進行胃癌における 術前SIS と短期および長期予後の関連性について検討した。2001 年 6 月から 2017年 4 月の間に、根治的胃切除術が施行された進 行胃癌症例のうち、術前SISが算出可能であった187例を対象と した。術前SISの増加に伴って、段階的にClavien-Dindo分類 grade 2 以上の術後合併症発生率は高くなっていた。術前SISは 年齢、肉眼的腫瘍径と有意な相関性を示した。SISにより術後全 生存期間、無再発生存期間ともに段階的に階層化され、その増加 とともに生存期間は短縮していた。

SISは切除可能進行胃癌において、術後短期および長期成績の簡 便かつ有用な予測因子となる可能性が示唆された。

\section{A11 ICG 蛍光法を用いた腹腔鏡下肝囊胞開空術} 一宮市立市民病院外科

浅井淨二、篠塚高宏、阪井満、橋本昌司、平山泰地、箕浦里恵、 高島幹展、佐藤文哉、藤田恵三、末岡 智、村井俊文、永田二郎 症例は69歳、女性。以前より肝囊胞を経過観察していたが、右季 肋部痛が出現し、手術方針となった。肝右葉を中心に最大 $16 \mathrm{~cm}$ 程度のものを含めて、肝囊胞が多発していた。全身麻酔導入後に、 ICG2.5mg を静注し、ICG 蛍光法で確認した胆管を損傷しないよ うに開空した。囊胞内䏶を観察し、肝内胆管との明らかな交通の ないこと、明らかな胆汁漏がないことを確認し、手術は終了した。 術後経過は良好であり、術後 4 日目に退院となった。腹腔鏡下肝 囊胞開空術において、ICG 蛍光法を用いることで簡便に胆道造影 を行うことができ、安全に手術を施行することができた。

\section{A12 肝切除術を施行した肝エキノコッカス症の 1 例} トヨ夕記念病院消化器外科

藤田康平、篠田憲幸、春木伸裕、点原裕樹、原田幸志朗、溝口公 士、加藤知克、傳田悠貴、津本知沙、辻 秀樹 症例は47歳男性。全身倦总感を主訴に受診。20代に北海道の牧場 に勤めていた。 1 年前から肝S 4 に石灰化を伴う不整形腫瘤を指 摘され経過観察されていた。今回腫瘤の増大を認めたため、精查。 エキノコッカス血清反応試験ウエスタンブロット法にて肝エキノ コッカス症と診断した。腫瘤はS4.5.8に存在しており中央 2 区域 切除術を施行した。病理組織診では虫体壁様構造物を認め、肝工 キノコッカス症に矛盾しない結果であった。再発予防目的にアル ベンダゾール内服を行っている。近年北海道以外でも同症の報告 が散見される様になった。肝腫瘤を指摘の際には、本疾患を念頭 に入れて診断し、適切な外科治療の介入が望まれる。 若干の文献的考察を加えて報告する。 


\begin{abstract}
A13腹腔鏡下肝切除を施行した膵インスリノーマ肝転移の
1 例

名古屋市立大学消化器外科 1 、NTT 西日本東海病院 ${ }^{2}$

葛谷宙正 1 松尾洋一1、上田悟郎 ${ }^{1}$ 、大見 関 1 、林 祐一1、今藤 裕之 1 、齊藤健太 1 、坪井 謙1、森本 守1 高橋広城1 石黒秀行 1 、 上田修久2 $、$ 福井拓治 2 、瀧口修司 ${ }^{1}$

症例は70歳女性。HCV 陽性。2011年に膵尾部インスリノーマに 対し他院で膵体尾部切除を施行。2012年に左原発性肺癌に対し当 院で左肺上葉切除を施行 (stage I B)。2018年 3 月に経過観察中 のCTで肝腫瘍を認め当科へ紹介となった。造影 CTで肝 S $5 / 6$ に20mm大の結節性病変を認め、早期で腫瘍周囲が膿染し平衡相 でwash outされるパターンを呈した。腫瘍マーカーは正常範囲 内であった。肝細胞癌または転移性肝腫瘍の術前診断で腹腔鏡下 肝拡大後区域切除術を施行し、合併症を認めず術後10日目に退院 となった。術後病理検查でインスリノーマの肝転移と最終診断し た。術前の確定診断は困難であったが, 腹腔鏡を用いることによ り低侵襲かつ再肝切除に対応しやすい治療が施行できたため報告 する。
\end{abstract}

A14緩和ケア目的に紹介された胃癌肝転移の患者に TACEを施行した一例

名古屋徳洲会総合病院外科 ${ }^{1}$ 同緩和ケア外科 ${ }^{2}$

田藏昂平1、坂本雅樹1,2、服部 卓1 、宋 潤錫 1 、今神 透 1 、松居 亮平1、高山 悟1、可児久典1

症例は81歳男性。前医にて胃癌に対し胃全摘術を施行したが、肝 転移が認められたため化学療法を開始した。化学療法の効果がそ しく、状態が悪化したため当院緩和ケア外科紹介となった。前医 での造影 CT にて肝 S 7 に胃癌の転移と考えられる $47 \mathrm{~mm}$ 大の占 拠性病変があり造影効果を認めた。前医からの情報では癌性腹膜 炎とのことだったが本人の積極的治療への意向が強く、また肝転 移の制御が予後を改善する可能性も期待できたため、当科にて TACEを施行した。術後全身状態良好で、術後 2 日目に退院、 術後15日目の外来フォローの際の造影 CTにて肝S 7 の占拠性病 変に壊死像を認め、治療効果を示したと考えられた。文献的考察 を加えて報告する。

\section{A15 遠位胆管腺扁平上皮癌の 1 切除例 \\ 小牧市民病院外科}

田中健士郎、杉本博行、大津智尚、岸田貴喜、小林大悟、山中雅 也、間下優子、野田純代、横山裕之、望月能成、谷口健次、末永 裕之

76歳、女性。嘔気、食欲不振を主訴に近医受診。黄疸を認め、腹 部USで膵頭部腫瘤があり当院紹介受診。腹部 CT 検査にて膵頭 部に $52 \mathrm{~mm}$ 大の腫瘤および上部胆管拡張、十二指腸浸潤を認めた。 遠隔転移は認めず。腹部 MRI検查で膵頭部腫瘤は T 1 WIで低信 号、T 2 WIで淡い高信号、DWIで高信号を示した。十二指腸壁 からの生検で腺扁平上皮癌を認め、PTBDにて減黄後、亜全胃温 存膵頭十二指腸切除術を施行した。病理組織学的診断は遠位胆管 腺扁平上皮癌 pT 3 a (pancreas, duodenum) N 1 M 0 fStage II Bであった。胆管原発の腺扁平上皮癌は比較的稀であり、その 1 切除例を経験したので報告する。
A16膵切除を施行した腎細胞癌膵転移症例の検討 名古屋市立大学大学院医学研究科消化器外科学 大見 関、松尾洋一、葛谷宙正、上田悟郎、林 祐一、今藤裕之、 齊藤健太、坪井 兼、森本 守、高橋広城、石黒秀行、瀧口修司 我々は2008年〜2017年に 5 例の腎細胞癌膵転移切除症例を経験し 良好な結果を得ている。外科切除の適応と治療成績を検討した。 平均年齢は67歳、男女比は $2: 3$ 、腎癌の手術から転移性膵腫瘍 の手術までの期間は平均120か月であった。術式は膵全摘術 1 例、 膵体尾部切除術 3 例、膵頭十二指腸切除術 1 例であった。 1 例は 膵体尾部切除術後 12 只目に残膵再発を認め残膵全摘術を施行し た。膵転移型式は単発 2 例、多発 3 例で、組織型はすべて淡明細 胞癌であった。2 例に他臓器再発を認めたが化学療法を併用し長 期生存を得ている（最終手術から平均94か月生存中）。 腎細胞癌膵転移は積極的な手術療法を中心とした集学的治療が予 後延長につながると考えられた。

\section{A17}

MCN との鑑別に苦慮した膵SCN macrocystic typeの 1 例

名古屋掖済会病院外科

加藤真司、長谷部圭史、米山文彦、木村桂子、加藤祐一郎、山口 直哉、向井俊貴、秋田由美子、尾入保彰、福井史弥、山内悠司、 杉田洋之、西野真史、日比野貴文、河野 弘

症例は51歳女性。数日間持続する腹痛精查のための腹部 CT 検查 にて、膵尾部に囊胞性病変を認め当院紹介受診。腹部 CT所見で は膵尾部に造影効果のある被膜を有し、内部に薄い隔壁を有する 内部低吸収な $40 \mathrm{~mm}$ 大の腫瘤を認めた。主膵管の拡張は認めなか った。MRIでは同部位にT 2 強調像で高信号な腫瘤を認め、 MRCPでは膵管との交通は認めなかった。EUSではCyst-incyst所見とともに、 lateral shadowを認め、厚い被膜の存在を疑 う所見も認めた。以上より MCNを第一に疑い、腹腔鏡下脾臓温 存膵体尾部切除術を施行した。切除標本の囊胞内には無色透明な 漿液性の液体を認めた。病理組織検查ではSCN macrocystic type と診断した。MCNとの鑑別に苦慮したSCN macrocystic typeの 1 例を経験したため報告する。

A18 ICG蛍光法により血流改善を確認した正中弓状勒帯症 候群を伴う膵頭十二指腸切除術の 1 例 名古屋大学大学院医学系研究科消化器外科学 中川暢彦、山田 豪、園原史訓、末永雅也、高見秀樹、林 真路、 丹羽由紀子、服部憲史、神田光郎、小林大介、田中千恵、中山吾 郎、小池聖彦、藤原道隆、小寺泰弘

症例は79歳、男性。正中弓状䩲帯症候群（MALS）を伴う膵頭部 癌の疑いで当院紹介となった。腹部血管造影検查では、呼気時に 腹腔動脈の狭窄が悪化し、上腸間膜動脈から優位に固有肝動脈が 描出された。MALS 合併膵頭部癌の術前診断で、亜全胃温存膵 頭十二指腸切除術を予定した。開腹し、正中弓状靼帯を切開して 圧迫を開放した後に、胃十二指腸動脈をクランプしてICGを静脈 投与すると、腹腔動脈から総肝動脈及び固有肝動脈の血流を良好 に確認することができた。MALSに対する術中血流評価にICG 蛍光法を応用した症例を報告する。 
A19 腸重積の原因となった若年性ポリープに対して腹脡鏡 下右半結腸切除術を行った 1 例

大垣市民病院外科

倉橋岳宏、金岡祐次、原田 徹、龟井桂太郎、前田敦行、高山祐 一、深見保之、高橋崇真、宇治誠人、川勝章司、三品拓也、吉川 晃士朗、伊藤喜介、岡本和浩、手嶋浩也、田中祐介、大屋勇人、 孫 起和、中川洋一、吉田大樹

症例は46歳の女性。下腹部痛の主訴で来院した。CT所見で上行 結腸の横行結腸への嵌入像を認め腸重積と診断された。下部消化 管内視鏡検査で肝湾曲部に 0 - I 型の腫瘍性病変を指摘された。 腸重積を発症し癌も否定できない上行結腸腫瘍として腹腔鏡下右 半結腸切除術を施行した。病理診断では若年性ポリープの所見で あり悪性所見は認めなかった。経過は良好で術後第11病日に退院 した。若年性ポリープは小児で多いが成人で腸重積を発症した報 告数は少なく良性疾患だが切除の対象となる。

\section{A20検診の便潜血陽性を契機に診断された下行結腸神経鞘 腫の 1 例 \\ 安城更生病院外科}

伊藤悠祐、平松聖史、佐伯悟三、雨宮 剛、後藤秀成、関崇、 陸 大輔、田畑光紀、藤枝裕倫、鈴木優美、岡本眞宗、崔 尚仁、 狩野陽子、齋藤麻予、余語孝乃助、佐藤誠洋、福山貴大、新井利 幸

症例は、78歳の男性で、検診の便潜血陽性を指摘され、精査目的 で当院紹介となった。大腸内視鏡検査で下行結腸に潰瘍形成を伴 う径 $20 \mathrm{~mm}$ 大の粘膜下腫瘍を認めた。生検にて神経原性腫瘍と診 断した。下行結腸粘膜下腫瘍と診断し、手術：下行結腸部分切除 術を施行した。病理学的に腫瘍は紡鍾形細胞からなり、免疫組織 学的に神経鞘腫と診断された。大腸の神経鞘腫は比較的まれな疾 患であり、潰瘍を形成し便潜血陽性を契機に診断されることはさ らにまれである。文献的考察を加え報告する。

\section{A21高カリウム血症改善剤の内服に関連する宿便性右側結} 腸穿孔の 1 例

春日井市民病院外科

谷口莉菜、有元淳記、古田美保、渡邊真哉、上遠野由紀、會津恵 司、佐藤文哉、玉井宏明、山田美保子、豊田良鎬、影山優美子、 三竹泰弘、山本泰資、岡本紗和子、李 昌史、山口竜三

[はじめに］宿便性大腸穿孔はS 状結腸から直腸での発生が殆ど で、右側では稀である。ポリスチレンスルホン酸カルシウム（ア ーガメート『、以下CSP）内服に関連する宿便のため右側結腸が 穿孔した症例を報告する。

[症例］86歳、女性。腎不全、心不全、喘息の既往があり、CSP 内服中であった。突然の腹痛のため救急搬送された。腹部全体に 筋性防御を伴う腹膜炎の所見であった。CTでは右側結腸間膜内 に便塊を認め、腹水を伴っていた。大腸穿孔と診断し、来院 4 時 間後に緊急手術を開始した。結腸右半切除、二連銃式人工肛門造 設、洗浄ドレナージを行ったが、敗血症性ショックのためPOD 1 に死亡した。
A22術前診断困難であった回盲部に多発した悪性リンパ腫 の 1 例 名古屋第一赤十字病院一般消化器外科 大野由以佳、神原祐一、湯浅典博、竹内英司、後藤康友、三宅秀 夫、永井英雅、吉岡裕一郎、奥野正隆、宮田完志 症例は74歳女性。検診の胸部 X線写真で右下肺野に異常陰影を認 めたため、当院を紹介された。肺癌を疑いFDG-PETを施行した ところ、右肺の結節の他に、回盲部に 1 ヶ所、FDGの高集積を 認めた。造影 CT で虫垂に腫瘤を認め、下部消化管内視鏡検査で 虫垂開口部に粘膜下腫瘍様の隆起を認めたため、肺転移を伴う虫 垂癌と術前診断し、回盲部切除、肺 S 6 区域切除を施行した。切 除標本では虫垂に径 $20 \mathrm{~mm}$ の 2 型腫瘍、回腸に径 $20 \mathrm{~mm}$ の 2 型腫 瘍、径 $15 \mathrm{~mm}$ と径 $10 \mathrm{~mm}$ の 1 型腫瘍を認めた。病理組織学的に虫 垂・回腸の 4 病変は全て diffuse large B-cell lymphomaで、右肺 の病変は扁平上皮癌であった。

A23 Micropapillary carcinomaを形成する直腸Ra浸潤癌 の切除例

名鉄病院外科

井岡大河、中山裕史、吉田光一、鳥居康二、菱田光洋、清水 稔、 黒川 剛、野菩英樹、小林裕幸

症例は70歳、男性。血便を主訴に当院受診。大腸内視鏡検査にて 直腸癌と診断され、低位前方切除術を施行した。

病理組織診断では異型腺管が絨毛腺管状に増生する Tubulo-villous adenomaを背景として、micropapillary patternを形成する 浸潤癌 (MPC) が認められた。NCCNのガイドラインでは乳癌・ 肺癌・膀胱癌等ではMPCの報告があるものの、大腸癌取扱い規 約にも記載がなく、本邦での報告症例数も少ないが、高率にリン パ管侵襲・リンパ節転移・遠隔転移を伴い予後不良と考えられて いる。2014年 5 月以降、当院にて MPCを含む直腸癌と診断され た症例は 3 例認めたが、うち 2 例はMPCを一部に認めるのみで、 腫瘍の大部分をMPCが占める本症例は比較的珍しい。病態が認 識されるにつれ、今後は症例報告数も増加してくると考えられる MPCについて、文献的考察を加えて報告する。

A24 左側結腸・直腸癌手術における Persistent descending mesocolon 症例 検討

名古屋市立大学病院消化器外科

柳田 剛、高橋広城、前田佑三、志賀一慶、廣川高久、原 賢康、 石黒秀行、松尾洋一、瀧口修司

Persistent descending mesocolon (PDM) は、発生過程での左 側結腸間膜と臓側腹膜の癒合不全が原因で、癒着や血管走行異常 を伴う。当院のPDM症例を検討した。[対象]2013年 4 月〜2017 年 3 月に腹腔鏡下手術施行した 203 例中、PDM 5 例を検討。

[結果]S 状結腸切除術 4 例、直腸前方切除・切断術 1 例でPDMを 認めた。手術時間は平均 6 時間を超えたが開腹移行なく、大きな 術後合併症なし。

[考察]術前・術中所見から PDM と診断した時は、間膜損傷や下 腸間膜動脈に近接する辺縁動脈損傷を起こさぬよう注意が必要と なる。 
A25 S 状結腸癌術後、腹膜播種・リンパ節再発との鑑別を 要した直腸間膜内結節性病変の 1 例

名古屋記念病院外科

冨永奈沙、越川克己、真田祥太朗、西 鉄生、福岡伴樹、佐野正 明

症例は62歳男性。 7 年前、S 状結腸癌に対して $\mathrm{S}$ 状結腸切除術を 施行し、最終診断はpT 4 b (膀胱) N 1 M 0、pStage III bであ った。術後補助化学療法後、右肺多発転移の診断で全身化学療法 および胸腔鏡下右下葉切除術を施行した。その後、定期検査の腹 部 CT で直腸間膜内に辺縁造影効果を有する $1.5 \mathrm{~cm}$ 大の結節性病 変を指摘された。PET-CTでは病変に一致してSUVmax8.3の集 積を認め、播種結節あるいは腸間膜リンパ節再発を疑い切除の方 針とした。腸間膜結節摘出術を行い、術後15日目に退院した。病 理検査では、リンパ球および形質細胞の浸潤と線維化を伴う炎症 性結節性病変と診断され、炎症性偽腫瘍やその類縁疾患群には分 類されなかった。同様の病態は稀であり、文献的考察を加えて報 告する。

A26 経肛門的低侵襲手術（TAMIS）により治療を行った 肛門異物に伴う直腸穿通の 1 例

名古屋市立大学病院消化器外科

加藤潤紀、高橋広城、柳田 風、前田祐三、廣川高久、志賀一慶、 原 賢康、石黒秀行、松尾洋一、瀧口修司

肛門異物は日常診療で時折遭遇するが、症例により手術による摘 出が必要となる。今回、経肛門的低侵襲手術（TAMIS）を用い て異物摘出を行った症例について報告する。

【症例】患者は認知症を認める83歳男性で、肛門からキリを挿入 した。緊急手術にて異物の摘出を経肛門的に試みるも、異物の腸 管穿通部を確認できず、TAMISにより摘出を試みた。その結果、 異物先端が腸管より離脱し、容易に異物摘出を行えた。術後は経 過良好で、合併症なく退院した。

【考察】近年、直腸腫瘍に対する TAMISの有用性が報告をされ ているが、肛門異物摘出における TAMISの有用性の報告はない ため、今回報告する。

A27 LECSにて切除しえた十二指腸腺腫の一例

名古屋市立大学大学院医学研究科消化器外科学

藤幡士郎、佐川弘之、中屋誠一、佐本洋介、大久保友貴、田中達 也、小川 了、坂本宜弘、高橋広城、松尾洋一、石黒秀行、瀧口 修司

症例は70歳代男性。検診の上部消化管内視鏡にて十二指腸下行脚 に $30 \mathrm{~mm}$ 大の LSTを指摘された。病理結果にて腺腫と診断され、 精查目的に紹介となった。当院で施行した上部消化管内視鏡では、 $30 \mathrm{~mm}$ 大でやや白色調のLST と、20mm大で発赤を伴う LSTが 隣り合っていた。合計 3 カ所からの生検を行ったがいずれも腺腫 であり、胸腹部 CTにて周囲リンパ節の腫脹および他臓器病変は 見られなかった。

悪性腫瘍の可能性は低いと判断し Laparoscopy Endoscopy Cooperative Surgery（LECS）による手術治療を行った。手術は上部 消化管内視鏡下にて腫瘍を確認し切除範囲を決定した。Kocher の受動後に全層切除を行い十二指腸と空腸を側々で吻合する Roux-en-Y再建を行った。術後病理結果で悪性成分は見られず、 十二指腸腺腫と䛦断され、術後 6 か月現在再発はみられない。 今回LECSにて切除しえた症例を経験したため、文献的考察を加 え報告する。
A28門脈・上腸間膜静脈血栓症に伴う小腸壊死の一手術例 愛知医科大学病院消化器外科

鈴木健太、小松俊一郎、金子健一郎、有川 卓、石黑成治、齊藤 卓也、駒屋憲一、松村卓樹、大澤高陽、倉橋真太郎、安井講平、 加藤翔子、加藤瑶子、佐野 力

症例は59歳、男性。腹痛を主訴に当院受診。造影 CTで一部小腸 の造影不良と肝内門脈から上腸間膜静脈末梢に至る広範な血栓形

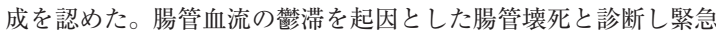
開腹術を施行した。1 $180 \mathrm{~cm}$ ぼの小腸壊死を認め壊死腸管の切除 を行った。今後腸管の血流障害が進行する可能性を考慮し双孔式 人工肛門を造設した。プロテイン $\mathrm{C} / \mathrm{S}$ 欠損症と診断され、血栓溶 解療法を行った。術後、経時的に血栓の縮小を認めた。術後11日 目に人工肛門閉鎖術を行い退院となった。門脈・上腸間膜静脈血 栓症に伴う小腸壊死の一例を経験した。その希少な事例を報告す る。

\section{A29 静脈性血管炎による限局性小腸壊死の一例}

名古屋第一赤十字病院一般消化器外科

鶴田成昭、湯浅典博、竹内英司、後藤康友、三宅秀夫、永井英雅、 吉岡裕一郎、奥野正隆、田中 宽、宮田完志

症例は77歳男性で、2018年 4 月心窩部痛、下血を主訴に当院を受 診した。既往に狭心症、高血压、高脂血症がある。下腹部を中心 に圧痛、反跳痛があり、血液検査にて炎症反応の上昇を認めた。 造影 CTにて骨盤内の小腸の造影不良扔よび腹水を認めたため、 虚血性小腸壊死と診断し、緊急手術を行った。術中所見では、回 盲部より約 $20 \mathrm{~cm}$ 口側の長さ約 $40 \mathrm{~cm}$ の回腸が浮腫状で暗黑色を呈 していたので、この部分を切除し、吻合した。切除標本肉眼所見 では縦走びらんの多発と暗黒色の粘膜を約 $40 \mathrm{~cm}$ の回腸に認め、 病理組織学的に静脈性血管炎による限局性小腸壊死と診断され た。

A30 鼠径ヘルニア術後13年目に小腸との瘦孔を来した遅発 性メッシュ感染の一例

豊川市民病院外科

植松 宏、堅田武保、阪本翔子、西土 徹、齋藤正樹、青山佳永、 柴田孝弥、彦坂 雄、三田圭子、柴田直史、寺西 太、柄松章司、 西田 勉

74歳男性、2005年に右鼠径ヘルニアに対し Mesh plug法による修 復術を施行した。2018年 2 月より右鼠径部の膨隆を自覚、増大傾 向で排膿を認めたため同年 4 月に当院受診された。右鼠径部は皮 虐が欠損し、白苔が付着していた。CT検査で右鼠径部筋層にガ ス像を認め、小腸との㾞孔形成が疑われたため小腸㿉、遅発性义 ッシュ感染と診断し同日入院となった。皮下のデブリードメント など感染コントロールをした後、入院13日目に腹腔鏡補助下で小 腸切除、メッシュ除去、腹壁再建術を施行した。術後経過良好で 術後24日目に退院となった。術後13年目の遅発性メッシュ感染に 対し一期的に根治術を施行した一例を経験したため若干の文献的 考察を加えて報告する。

\section{A31 IgG 4 関連小腸リンパ節症の 1 例}

安城更生病院外科

佐藤誠洋、佐伯悟三、平松聖史、雨宮 剛、後藤秀成、関崇、 陸 大輔、藤枝裕倫、田畑光紀、鈴木優美、崔 尚仁、岡本眞宗、 齋藤麻予、余語孝乃助、狩野陽子、福山貴大、新井利幸 症例は69歳の男性。慢性腎不全のため、腹腔鏡下 CAPD カテー 
テル留置目的に当科受診した。手術時に腹腔内を観察した際、小 腸と小腸間膜に連続する腫瘤性病変を認めた。小腸粘膜下腫瘍と 術中診断し、小腸部分切除術を施行した。病理検查では、腫瘤は 腸間膜を主座とし、リンパ滤胞間に IgG 4 陽性形質細胞の浸潤を 認めた。血中 $\operatorname{IgG} 4$ も上昇を認め、 IgG 4 関連リンパ節症と診断 した。IgG 4 関連疾患は近年生まれた疾患概念であり、その病態 は未だに不明なことが多い。 IgG 4 関連小腸リンパ節症の報告は まれであるので文献的考察を加え報告する。

A32 悪性リンパ腫の化学療法中に発症した小腸穿孔の 1 例 豊橋市民病院一般外科

長谷川环哉、神谷忠宏、平松和洋、柴田佳久、吉原 基、青葉太 郎、伊藤 哲、前田周良、毛利康一、小林龍太朗、梅村将成、滝 本愛太朗、野中有紀子、荒川拓也、伊藤量吾、権田紘丈、柴田淳 平、加藤岳人

症例は78歳女性。びまん性大細胞型 B 細胞リンパ腫 stage III sに 対して、R-CHOP療法を導入した。導入 5 日目より腹痛を認め、 8 日目に腹痛が増悪した。CT検查でfree airを認め、消化管穿 孔と診断し同日緊急開腹手術を施行した。術中所見で、回盲部か ら $10 \mathrm{~cm}$ 口側の小腸に径 $3 \mathrm{~mm}$ の穿孔を認め、小腸部分切除を行っ た。病理組織学的所見は、穿孔部位に炎症細胞浸潤を認めるのみ で腫瘍細胞浸潤を疑う所見はなかった。今回我々は悪性リンパ腫 の化学療法中に発症した小腸穿孔の 1 例を経験したので報告す る。

A33卵巣囊腫茎捻転により癒着性イレウスを発症した 1 例 八千代病院外科

花澤隆明、圭野泰司、小林一郎、松原秀雄、金子博和、葉原聖実、 山本龍生、二村雄介、弥政晋輔

症例は94歳女性、便秘と腹痛で受診した。CTで下腹部に最大径 16センチの左卵巣囊腫と癒着性イレウスを認めた。イレウス管減 圧で改善し食事摂取再開するもイレウス再燃を繰り返した。高齢 であり保存治療を行っていたが、入院 28 日目に試験開腹術を行っ た。下腹部正中で開腹すると、卵巣囊腫表面に小腸が癒着しイレ ウスの原因となっていた。小腸を卵巣囊腫から剥離し一部損傷し た小腸を切除した。卵巣囊腫は茎捻転しており、これを摘出した。 術後11日目で経過良好で退院となった。卵巣囊腫茎捻転がイレウ スの原因となることは非常に稀であり、若干の文献考察を加え報 告する。

A34 腸閉塞症例に対する $3 \mathrm{D}-\mathrm{CT}$-enterography の意義 名古屋第一赤十字病院一般消化器外科

長尾拓哉、湯浅典博、竹内英司、後藤康友、三宅秀夫、永井英雅、 吉岡裕一郎、奥野正隆、田中 寞、宮田完志

近年、クローン病などの小腸疾患に対する画像検査として、CTenterography またはMR-enterographyが使用されることがあ る。これらは検查施行前に造影剤を内服し、腸管を進展させた状 態でCT またはMR行うことで腸管を $3 \mathrm{D}$ 構築して描出すること が出来る。今回我々はMDCTにて closed-loop を疑った腸閉塞の 3 症例に対し、腸管内䏕に造影剤を投与することなく、CT-enterographyを構築した。これにより、closed-loop となった腸管 の閉塞・屈曲の具合が客観的かつ容易に理解できるようになった。
B1 乳癌脈絡膜転移の 1 例と当院における乳癌眼部転移症 例の検討

小牧市民病院外科

久留宮早織、間下優子、野田純代、横山裕之、杉本博行、望月能 成、谷口健次、末永裕之

症例は76歳女性。左乳癌（ホルモン陽性、HER 2 陰性）で乳房 温存手術 +センチネルリンパ節生検施行。術後補助療法は施行せ ず経過観察。術後 9 年 5 ケ月で肺、骨、縦隔リンパ節再発にてホ ルモン療法とデノスマブを開始。治療経過中、右上半分の視野欠 損を主訴に眼科受診し脈絡膜転移の診断。ホルモン療法の継続に て脈絡膜転移から11ケ月、視野異常の悪化を認めていない。当院 での2000 2017年の原発性乳癌2,293例中、眼部（脈絡膜、眼窩内、 眼筋）転移は 7 例。確立した眼部転移の治療はないが視機能を維 持することは全身治療を継続する上で重要である。文献的考察を 加え、報告する。

\section{B2 乳腺平滑筋過誤腫の 1 例}

大垣市民病院外科

松井真実、金岡祐次、原田 徹、龟井桂太郎、前田敦行、高山祐 一、樑見保之、高橋崇真、宇治誠人、川勝章司、三品拓也、伊藤 喜介、吉川晃士朗、岡本和浩、田中祐介、手嶋浩也、大屋勇人、 孫 起和、中川洋一、吉田大樹

症例は60歳女性。8 年前に左乳房 D 領域の $15 \mathrm{~mm}$ 大の腫瘤を主訴 に受診。穿刺吸引細胞診では良性、画像所見から過誤腫と診断し、 半年ごとの経過観察となった。腫瘤は緩徐に増大し、半年前は $37 \mathrm{~mm}$ であったが、今回は $54 \mathrm{~mm}$ と急速な増大を認めた。針生検 で平滑筋過誤腫が疑われたが増大傾向であり、診断治療目的に腫 瘤摘出術を施行した。病理組織所見では二相性を保つ乳管上皮と 間質の増殖、間質での脂肪組織と平滑筋束の増生を認めた。免疫 染色を行い、p63、 $a$-SMA、E-cadherin陽性であり、乳腺平滑 筋過誤腫と診断した。今回我々は乳腺腫瘍性病変において稀な疾 患である乳腺平滑筋過誤腫の 1 例を経験したので報告する。

B3 功例の検討

名古屋市立西部医療センター乳腺・内分泌外科1、SL外科・乳腺 クリニック2、あんどう乳腺クリニック 3

高野崇継1、加藤明子1、鎗山憲人1、伊藤由加志2、安藤由明3、川 瀬麻衣、杉浦博士 ${ }^{1}$

HER 2 陽性進行再発乳癌の一次治療に扔いて、トラスッズマブ （H）+ドセタキセル（D）にペルツズマブ（P）を併用すると無 増悪生存期間、全生存期間ともに有意に延長することがCREOPATRA 試験で示された。2017年11月までに当院でHPD療法を 行った18例を後方視的に検討したので報告する。く結果＞平均年 齢は63.6歳。最大効果はPRが11例、SDが 4 例、PDが 3 例であ った。2 例は忍容性が良好で、それぞれ35コース、27コース投与 した。4 例は病勢進行のため中止、12例は D の副作用のため中止 となった。この12例は全てHP+ホルモン療法を行っているが、 このうち 10 例では $\mathrm{D}$ 中止後も病勢進行を認めていない。最大効果 でPRを得た症例は、ER陽性群・1 stライン治療群に多い傾向で、 また有意に奏功期間が長かった。く考察> HPD 療法で奏功した 症例は、 $\mathrm{D}$ 中止後も効果が継続する症例が多い可能性がある。今 後 HPD 療法を行う場合、Dの至適投与期間を検討する必要があ る。 
B4 整容性と根治性を兼ねた新しい取り組み Areola-sparing mastectomy

名古屋市立大学病院乳腺外科 1 同形成外科 ${ }^{2}$

片桐悠介 ${ }^{1}$ 、久田知可 ${ }^{1}$ 、近藤直人 1 、鰐㴊友美 ${ }^{1}$ 、上本康明 ${ }^{1}$ 、西川 さや香 1 、佐藤秀吉 2 、鳥山和宏 2 、遠山竜也 ${ }^{1}$

乳癌に対する人工物による乳房再建術が保険適応となり、近年再 建術は増加傾向である。その際の術式として、乳房皮膚を温存す る皮膚温存乳房全切除術 (skin-sparing mastectomy:SSM)、乳 房皮虚および乳頭乳輪を温存する乳頭温存乳房全切除術 (nipplesparing mastectomy:NSM）が一般的である。NSMにおいては乳 頭部の乳腺組織が残存することから、同部の局所再発に少なから ず影響すると考えられている。一方でSSMでは乳輪も切除する ため再建後の整容性も保ちにくい。そこで当院では、根治性と整 容性を兼ねた術式として、乳房皮膚および乳輪を温存する乳頭く りぬき乳輪温存乳房切除術 (areola-sparing mastectomy:ASM) を取り入れ始めたので報告する。適応は腫瘍直上の皮膚切除が必 要とならないこと、乳輪直下に病変がないこととしている。さら にNSMの適応も患者が乳頭を含めた乳房全切除術を希望された

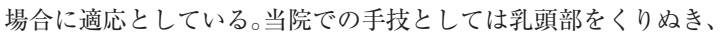
外側に $6 \mathrm{~cm}$ の皮膚切開を置いている。さらに乳房の大きな場合 は乳輪内に横切開を加えている。SSMに比較して、くりぬく範 囲が小さいので皮弁の作成のはじめはやや難しいが、ある程度の 皮弁作成ができれば、その部分に創縁保護かつ、視野確保目的に リトラクターを装着可能であり、最終的にはSSM と変わらない。 NSM と比較すると乳頭部からの操作が可能であり乳房内側の皮 弁作成は容易である。当院では最終的に乳頭くり抜き部分は縫縮 し、一期的に乳頭再建も行っている。欠点としては健側と比へ患 側の乳輪、乳頭が小さくなることがあげられる。まだ症例数は少 ないが、形成外科と連携が可能であれば根治性と整容性のいずれ も両立できる新しい術式である。

B5 甲状腺癌術後10日目に発症した遅発性術後出血の一例 トヨ夕記念病院乳腺内分泌外科

上原侑里子、西本真弓、伊藤和子

症例は30歳女性。甲状腺左葉に径 $1.4 \mathrm{~cm}$ の腫瘍を認め、細胞診で 乳頭癌と診断されたため、甲状腺左葉切除術 + 䅡部リンパ節郭清 （D 1 郭清）を施行した。経過良好にて術後 4 日目で退院となっ たが術後10日目に頝部の腫脹、呼吸苦が出現した。CTで右側優 位に頚部の血腫を認め、気管は左方に偏位していた。気道閉塞の 危険性が高いと判断、緊急に挿管し、止血術を施行した。術中所 見では右側の胸骨舌骨筋と胸骨甲状筋の筋間に最も血腫を認め、 初回の手術で正中切開した前頚筋群の下縁筋層内から静脈性出血. を認めた。術後は経過良好で術後 5 日目に退院となった。一般的 に術後出血は24時間以内の発症が多いとされ、甲状腺では気道閉 塞を引き起こし致死的となりうるため緊急処置を必要とする。今 回、術後 10 日目と遅発性に発症した比較的稀な術後出血症例を経 験したため報告する。

\section{B6 網谷病に肺癌を合併した 1 例}

名古屋市立西部医療センター呼吸器外科 1 、同病理診断科 ${ }^{2}$

山中菜摘、幸 大輔 1 、中前勝視、小林瑞穂 ${ }^{2}$

症例は71歳、男性。CTにて上葉優位に肺瀻維化を認め、以降特 発性上葉限局型肺線維症（以下、網谷病）として経過観察をして いた。経過中、右上葉 S $2-\mathrm{S} 3$ 間の中枢側に、大きさ $3.3 \times 3.3 \times$ $3.2 \mathrm{~cm}$ の斑状病変を認めた。病変は経時的に増大を認め肺癌が疑
われた。そのため診断、治療目的に胸望鏡補助下右上葉切除術を 施行した。術後病理診断にて腺癌（pT 1 a N 0 M 0) と診断された。 特発性間質性肺炎に合併する肺癌は末梢型であることが多く、早 期発見困難例もしばしば認められる。一方、本症例は中枢側に病 変を認め、纎維化と離れていたため早期発見、根治切除に至った。 網谷病に肺癌が合併した非常に稀な症例を経験したので報告す る。

\section{B7 肺血栓塞栓症合併肺癌の 1 切除例}

名古屋記念病院外科

佐野正明、冨永奈沙、真田祥太朗、西 鉄生、福岡伴樹、越川克 己

症例は76歳男性。下血を主訴に当院初診。精查にて直腸癌と右上 葉の腫瘤性病変を指摘された。直腸癌に対して低位前方切除術を 施行。術後縫合不全のため治療を要した。4 か月後、造影 CT 検 查にて肺動脈血栓塞栓症と深部静脈血栓症が判明し、抗凝固療法 を施行し、下肢静脈血栓は消失し、肺動脈血栓塞栓は縮小した。 直腸癌術後 7 か月後右上葉切除術を施行した。悪性腫瘍に深部静 脈血栓症や肺動脈血栓塞栓症が高率に合併することは周知の事実 であるが、肺血栓塞栓症を伴った肺切除の報告は稀である。若干 の考察を加え報告する。

\section{B8} 肺癌検診で指摘された巨大胸膜原発孤立性線維性腫瘍 の一例

$\mathrm{JA}$ 愛知厚生連江南厚生病院外科

岡戸翔嗣、福井高幸、斎藤悠文、野々垣彰、中村正典、山中美歩、 間下直樹、渡邊卓哉、飛永純一、石榑 清

症例は77才女性、身長 $153 \mathrm{~cm}$ 、体重 $41 \mathrm{~kg}$ 。検診の胸部 X線検查で 右胸水を指摘され当院紹介となった。胸部 CTで右胸水と右胸壁 背側に接する $150 \times 126 \mathrm{~mm}$ の腫瘤を認めた。CT ガイド下生検で 孤立性線維性腫瘍の診断となり、腫瘍摘出術を施行した。腫瘍は 表面平滑であり、肺や胸壁との癒着はなく、下大静脈付近の胸膜 と連続していた。隣接臟器を損傷することなく完全摘除した。合 併症なく経過し、術後 7 日目に退院となった。摘出腫瘍の病理組 織診断は孤立性線維性腫瘍であり、切除断端は陰性であった。胸 膜原発孤立性線維性腫瘍は胸膜中皮下の間葉組織に由来する比較 的頻度の低い腫瘍である。治療法は完全な腫瘍摘除であり、予後 は一般に良好で局所再発や遠隔転移はまれである。文献的考察を 加えて報告する。

\section{B9 術前診断が困難であった孤立性線維性腫湯の 1 例} トヨ夕記念病院外科・呼吸器外科

石田雅揮、上原侑里子、辻 卓真、森山悟、齋藤雄史、佐竹 章、 山川洋右

症例は77歳男性。主訴：胸痛。胸部 $\mathrm{x}$ 線写真にて右肺門部腫瘤影 を指摘され紹介。 1 年前の胸 $\mathrm{x}$ 線写真より増大、CTでは右上葉 肺門部に $40 \mathrm{~mm}$ 大の比較的境界明瞭な腫瘤、上行 A 3 動脈が腫瘍 内を貫通する所見、後期相で強い造影効果を認めた。PET検查 ではSUVmax2.04、軽度FDG集積を呈した。カルチノイド、硬 化性血管腫などを疑い右肺上葉切除を行った。病理組織学的には 紡錘型細胞が膠原線維とともに密に増殖、鹿角状血管をともなっ た patternless patternを示し、CD34、STAT 6 陽性で孤立性線 維性腫瘍 SFT と診断された。壊死、浸潤性増殖なく、核の多形 性乏しく核分裂像少数で良性と考えられた。比較的まれな SFT を経験し文献的考察を加え報告する。 
B10甲状腺癌多発肺転移を疑った転移性子宮筋腫の一例 刈谷豊田総合病院呼吸器外科

細川 真、鈴木あゆみ、遠藤勝彦、山田 健 症例は手術歴として 5 年前に甲状腺癌、 2 年前に子宮筋腫の罹患 がある45歳女性。 3 年前から右中葉に結節影を認め、増大傾向に あったため甲状腺癌の肺転移を疑い当科へ紹介となった。CT上、 中葉に辺縁明瞭・境界整な $6 \mathrm{~mm}$ 大結節影を認め、PETでの集 積を認めなかった。手術は第 4 肋間に $2.5 \mathrm{~cm}$ の UtilityThoracotomy、第 6 肋間にポートを 2 か所追加した。腫瘍は 3 葉合流部の 腹尾側に触知し、マージンをとって部分切除を施行した。病理診 断で $1-2 \mathrm{~mm}$ 大の無数の平滑筋腫を認め、甲状腺癌所見は認めず 子宮筋腫の転移と診断された。

子宮筋腫は良性だが肺転移をきたすことが報告されており、女性 の場合辺縁明瞭・境界整な肺結節では子宮筋腫を鑑別に挙げる必 要はあるが、非常に希少である。

本症例では切除検体内に小結節が散在しており、今後はホルモン 療法の適応と考える。

\section{B11 子宮内膜腺癌の孤立性転移性肺腫瘍の 1 例} 名古屋市立大学大学院医学研究科腫瘍・免疫外科

横田圭右、羽田裕司、奥田勝裕、立松 勉、坂根理司、小田梨紗、 渡邊拓弥、中西良一

症例は67歳、女性。既往歴として、63歳時に子宮内膜腺癌にて他 院で準広範子宮全摘、後腹膜リンパ節郭清術の治療歴があった (pStage II)。検診胸部レントゲンにて右肺門部に腫瘤影を認め、 当院を紹介受診。胸部 CT にて右肺中葉 S 5 に最大径 $46 \mathrm{~mm}$ 大の 腫瘤を認め、縦郭脂肪織への浸潤が疑われた。PET検査では右 肺腫瘍にSUVmax10.29の FDG集積を認め、その他に異常集積は 認めなかった。気管支鏡検查では細胞診にて疑陽性（cellular atypia）の結果で、原発性肺癌の疑い（cT 3 N 0 M 0 cStage III A) で胸腔鏡下右肺上中葉切除、ND $2 \mathrm{a}^{-} 1$ 郭清を施行。横隔神経は 腫瘍浸潤のため合併切除した。術後経過は良好で術後 6 日目に軽 快退院し、摘出標本の病理検查にて、子宮内膜腺癌の転移性肺腫 瘍と診断された。一般に子宮原発悪性腫瘍の肺転移はまれである が、子宮内膜腺癌は血行性に腹腔外への遠隔転移を来すことがあ る。子宮内膜腺癌の既往がある場合には、転移性肺腫瘍の可能性 も念頭に置くべきである。

\section{B12 若年自然気胸に関する前向き臨床試験}

愛知医科大学病院呼吸器外科

古田ちひろ、矢野智紀、田口瑠美子、山地雅之、沼波宏樹、羽生 田正行

今回、若年自然気胸術後ブラの新生と気胸再発についての前向き 臨床試験を開始したため報告する。平成 28 年 7 月〜当院で自然気 胸に対し肺囊胞切除術を施行した30歳以下の症例を対象とし、術 後半年、 1 年後にブラの新生と気胸の再発有無を観察した。登録 症例は20例、平均年齢は17.9歳であった。半年後のCTが終了し た 10 例中 4 例、 1 年後には 8 例中 5 例にブラの新生を認めた。新 生ブラは主にstaple line上に分布していた。術後 1 年の再発は 3 例で、1 例は再手術を施行した。術後ブラの新生は遅くとも半年 以内に始まり、経時的に増加する傾向を認めた。再発に影響する 因子については、今後さらなる症例の蓄積と十分な検討が必要で あると思われる。
B13魚骨穿通による膿瘍を形成した大網腫瘤の 1 例 安城更生病院外科

狩野陽子、平松聖史、佐伯悟三、雨宮 剛、後藤秀成、関崇、 陸 大輔、藤枝裕倫、鈴木優美、岡本眞宗、崔 尚仁、齋藤麻予、 余語孝乃助、佐藤誠洋、福山貴大、新井利幸

患者は75歳の男性。左上腹部痛あり近医を受診し、CRPの上昇 を指摘、当院紹介となった。造影 CTでは、横行結腸近傍の大網 に腫瘤形成を認め、内部にCT值の高い異物を認めた。抗生剂投 与による保存的治療を行ったが、第 3 病日の採血、CTで改善が 得られず、同日、腹腔鏡下手術を施行した。大網腫瘤は横行結腸 に近接していたが、連続性はなく、横行結腸には、憩室炎や穿孔 を認めなかった。大網腫瘤を一塊に摘出した。切除標本の病理組 織学的検査では、腫瘤は内部に膿瘍を形成し、約 $1 \mathrm{~cm}$ 長の魚骨と 思われる異物を含んでいた。魚骨の不顕性穿通によって膿瘍を形 成した大網炎症性腫瘤と診断した。

B14 魚骨による十二指腸穿孔の 1 例

名古屋市立東部医療センター外科

浅井宏之、谷脇 聡、木村昌弘、柴田康行、水野幸太郎、越智靖 夫、長崎高也、上野修平、江口祐輝

症例は85歳男性。ブリを食べた 2 日後、右季肋部痛にて救急搬送 された。腹部超音波検查、CT とも十二指腸壁を貫き胆囊との穿 通を疑わせる異物を認め、壁外にわずかな air と周囲脂肪織濃度 上昇、腹水を認めたため緊急手術を施行した。十二指腸球部前壁 を $3 \mathrm{~mm}$ 程度貫通する魚骨を認めたが、胆囊穿通は認めなかった。 内腔からの観察を目的に挿入した内視鏡にて魚骨摘出し、腹腔鏡 下に穿孔部の縫合閉鎖と腹腔内洗浄ドレナージを行った。術後経 過は良好で第11病日に退院となった。魚骨による腸管穿孔は下部 消化管や食道に多く、十二指腸は稀である。

本例では超音波検查より胆囊穿通と術前診断したが、胆囊内の線 状のアーチファクトと考えられた。CT所見を合わせ興味ある画 像所見であった。

B15魚骨穿孔を契機に膵癌の横行結腸播種が発見された一 例

名古屋市立西部医療センター消化器外科

松本奈々、早川俊輔、加藤裕子、森本翔太、渡部かをり、高須惟 人、社本智也、若杉健弘、三井 章、葉原義之

症例は84歳男性。左下腹部痛を主訴に当院を受診した。腹部造影 CTにて脾弯曲部に液体譻留とfreeair 認めたため、下部消化管 穿孔の診断にて緊急手術を施行した。穿孔部には魚骨を認め、魚 骨による横行結腸穿孔と診断し、穿孔部の腸管を切除して横行結 腸にて人工肛門を造設した。術後、病理検査にて、穿孔部の腸管 漿膜側に上皮内まで浸潤する膵癌組織を認め、膵癌播種による横 行結腸の内垫狭窄部に魚骨が刺入したことによる穿孔と考えられ た。本症例は、消化管穿孔の症例において、腸管に明らかな腫瘍 を認めない場合でも、㓔痕等がある場合は病理組織学的な検索が 重要であることを示唆している。

B16 腹部大動脈瘤術後に発生した難治性十二指腸瘦の 1 例 豊橋市民病院一般外科

柴田淳平、青葉太郎、加藤岳人、平松和洋、柴田佳久、吉原 基、 神谷忠宏、伊藤 哲、前田周良、毛利康一、梅村将成、小林龍太 朗、滝本愛太朗、野中有紀子、荒川拓也、伊藤量吾、権田紘丈 75歳男性。腹部大動脈瘤破裂に対し近医にて緊急 I-graft置換術 
を施行後、S 状結腸穿孔のため当院搬送され、緊急人工肛門造設 +ドレナージ術を施行した。術後ドレーンより腸液の排出を認め たが保存的に軽快し退院となった。半年後に腹部仮性動脈瘤を認 め緊急ステントグラフト挿入術 (e-EVAR) を前医にて施行。ド レーンより腸液流出を認め当院搬送となった。ドレーン造影にて 十二指腸との瘦孔を認めたが全身状態に問題はなくドレーン挿入 下では経口摂取可能である。人工物挿入下の腸管漏は難治性であ り治療に難渋する。今回、I-graft、e-EVAR挿入下での腸管漏 の保存的治療を経験したので文献的考察を加え報告する。

B17 播種性血管内凝固症候群（DIC）を伴う穿孔性虫垂炎 に起因した上腸間膜静脈、門脈血栓症の 1 例

春日井市民病院外科

三竹泰弘、山口竜三、古田美保、渡邊真哉、上遠野由紀、會津恵 司、佐藤文哉、玉井宏明、有元淳記、山田美保子、豊田良鎬、影 山優美子、山本泰資、岡本紗和子、李 昌史

症例は67歳の男性。主訴は発熱。受診 3 日前から発熱を認め血圧 が低下したため当院へ紹介となった。体温37.6度、血圧 94/59mmHg、脈拍107回/分であった。右下腹部に圧痛を認めた が腹膜刺激兆候は認めなかった。血液検查で炎症反応の上昇と血 小板低下と腎機能障害を認めた。単純 CT T゙虫垂の腫大を認めた。 敗血症性ショックとDICを伴う急性虫垂炎と診断し、虫垂切除、 洗浄ドレナージ術を施行した。術後は集中治療管理を行った。造 影CTを撮影すると上腸間膜静脈から門脈右枝へ続く血栓を認め ヘパリンを開始した。ICU退室後に麻痺性イレウス、創感染など 認めたが軽快し術後31日目に退院した。

\section{B18穿孔性虫垂炎術後化膿性肉芽腫を形成した虫垂放線菌 \\ 症の 1 例}

名古屋掖済会病院外科

葉原聖実、米山文彦、木村桂子、加藤祐一郎、山口直哉、向井俊 貴、長谷部圭史、秋田由美子、福井史弥、山内悠司、西野真史、 杉田洋之

症例は81歳女性。平成29年 8 月、穿孔性虫垂炎に対し虫垂切除、 洗浄ドレナージを施行した。退院 4 ケ月後に右季肋部痛を主訴に 受診。腹部造影CTで肝下面から右側腹壁にかけて、限局する不 均一な脂肪織濃度の上昇を認めた。遺残膿瘍と判断しレボフロキ サシン $500 \mathrm{mg} /$ 日を内服するものの腹部症状は改善せず、平成 30 年 1 月に手術を施行した。右季肋部の後腹膜から右側腹壁にかけ て化膿性の肉芽組織を認めたため可及的に掻爬した。術後切除標 本から放線菌が確認された。肉芽組織の完全切除は不可能であっ たためアモキシシリン $1,500 \mathrm{mg} /$ 日を半年間内服する方針とした。 穿孔性虫垂炎術後に遺残膿瘍を認めた場合は放線菌症を念頭に置 く必要がある。

\section{B19 白血病治療中に発症したムコールによる急性虫垂炎の \\ 1 例}

豊橋市民病院一般外科

荒川拓也、伊藤 哲、加藤岳人、平松和洋、柴田佳久、吉原 基、 青葉太郎、神谷忠宏、前田周良、毛利康一、梅村将成、小林龍太 朗、滝本愛太朗、野中有紀子、伊藤量吾、権田紘丈、柴田淳平 症例は29歳の女性。AML（急性骨髄性白血病）に対し寛解導入 療法を行っており、好中球減少症を認めていた。 $37.5^{\circ} \mathrm{C}$ の発熱と 腹痛が出現、下腹部に強い圧痛と筋性防御認めた。CTでは回腸 末端の高度浮腫と造影不良、腹水を認め腸管壊死を疑い、緊急手
術とした。術中所見で壊疽性虫垂炎と診断し、虫垂切除術を施行 した。虫垂に接する小腸に色調不良を認めたが、小腸壊死はない と判断し小腸切除は施行しなかった。切除標本では虫垂腔内に高 度な糸状菌の増殖を認め、ムコールによる虫垂炎と診断した。術 後抗真菌薬による治療を行い経過は良好で術後 3 か月現在、手術 関連合併症は認めていない。ムコールによる急性虫垂炎は極めて まれであり、若干の文献的考察を加えて報告する。

B20 虫垂切除術を契機に偶発的に診断された虫垂神経内分 泌腫瘍の 1 例

安城更生病院外科

福山貴大、平松聖史、佐伯悟三、雨宮 剛、後藤秀成、関崇、 陸 大輔、田畑光紀、藤枝裕倫、鈴木優美、岡本眞宗、崔 尚仁、 狩野陽子、齋藤麻予、余語孝乃助、佐藤誠洋、新井利幸 症例は 19 歳の男性で、受診する 1 年程前より月に 1 回程度の右下 腹部痛を自覚していた。腹痛高度となり嘔吐も出現したため当院 を受診した。CTにて腫大する虫垂を認め、急性虫垂炎とした。 保存的治療を行い、 5 力月後待機的に腹腔鏡下虫垂切除術を施行 した。切除した虫垂に径 $8 \mathrm{~mm}$ 大の腫瘍性病変を認め、病理組織 学的に神経内分泌腫瘍 (G 1) と診断した。切除断端は陰性であ った。術後 6 ケ月経過し再発を認めず経過観察中である。虫垂炎 手術を契機に偶発的に診断された若年者の虫垂神経内分泌腫瘍の 1 例を経験したので、文献的考察を加え報告する。

B21当院における急性虫垂炎手術症例の検討

$\mathrm{JA}$ 愛知厚生連豊田厚生病院外科

佐久間政宜、久留宮康浩、水野敬輔、世古口英、菅原 元、河合 清貴、桐山宗泰、鳥居直矢、蟹江恭和、稲田亘佑、今村由人、関 本晃裕、竹内健司

当院では急性虫垂炎に対する腹腔鏡手術が増加傾向であり、治療 成績の検討を目的とし、2013年抢よび2017年における急性虫垂炎 手術症例を対象に比較した。2013年では開腹117例（94.4\%)、腹 腔鏡 7 例 $(5.6 \%)$ であり、2017年では開腹29例 $(23.2 \%) 、$ 腹腔 鏡96例（76.8\%）であった。両群の BMI、WBC、CRP、CT上の 膿瘍形成または穿孔率に差は認めなかった。合併発症率は2013年 で16例（12.9\%)、2017年で11例（8.8\%）であった。また、2013 年の小開腹 112 例と 2017 年の腹腔鏡 96 例を比較すると、壊疽性虫 垂炎は2013年39.1\%、2017年 $45.8 \%$ であり、合併症発症率は 2013年 $8.18 \%$ 、2017年8.33\%であった。腹腔鏡手術増加により合 併症減少、および壊疽性虫垂炎に対する腹垫鏡手術の有用性が示 唆された。

B22

安全に修復しえたCVポートカテーテル先端位置異常 の 1 例

小牧市民病院外科

小林大悟、田中健士郎、小池 翠、大津智尚、岸田貴喜、山中雅 也、間下優子、野田純代、横山裕之、杉本博行、望月能成、谷口 健次、末永裕之

症例は63歳女性。身長 $147 \mathrm{~cm}$ 、体重 $50 \mathrm{~kg}$ 。閉塞性黄疸を認め近医 より紹介。精查にて切除不能進行胃癌と診断。化学療法目的に右 鎖骨下静脈へアプローチし CV ポート造設術を施行。術後 2 ケ月 頃、CVポート穿刺不可にて当科受診。診察すると、CVポート が反転。立位レントゲンにて、CVポートは尾側へ偏位しカテー テル先端が浅くなっていた。局所麻酔下、CVポート再留置術を 施行。同創部を切開し、反転を修復。大胸筋前筋膜を露出し縫合 
固定。術後立位レントゲンにてカテーテル先端位置異常は改善。 今回、安全に修復しえた CV ゚゚ートカテーテル先端位置異常の 1 例を経験したので、若干の文献的考察を加えて報告する。

\section{B23腹腔鏡下にチューブ位置調整を行い改善し得た腹腔内} 髄液仮性囊胞の 1 例

公立陶生病院外科

野亦悠史、大河内治、清水三矢、江坂和大、林 直美、岡本喜一 郎、松下英信、川瀨義久

症例は27歳男性。生後 5 ケ月時に水頭症のため V-P シャント術 を施行されている。今回、腹部膨満感、腹痛を自覚し救急外来を 受診した。腹部は著明に緊満し、腹部CTで腹腔内に隔壁を伴う 巨大な囊胞を認め、髄液仮性囊胞の診断で同日手術となった。腹 腔鏡下に観察すると腹壁に囊胞の広範な癒着認めた。囊胞壁を剥 離し内胿に到達するとシャントチューブが確認でき、先端を骨盤 底に位置調整した。術後経過は良好で第 6 病日に退院となった。 腹腔内髄液仮性囊胞は水頭症手術に関連して生じる比較的稀な疾 患であり、先行報告はあるが、その治療法は患者、施設によって 様々である。今回、我々は腹腔鏡下でのチューブ位置調整によっ て改善し得た 1 例を経験したため過去の報告の検討を交えつつ報 告する。

B24腹腔鏡下に切除した仙骨前面の後腹膜神経鞘腫の 1 例 刈谷豊田総合病院消化器・一般外科 ${ }^{1}$ 同腹腔鏡ヘルニアセンタ $-2$

上原崇平1、小林建司 ${ }^{1} 、$ 野々山敬介 ${ }^{1}$ 、辻 恵理 ${ }^{1}$ 北山陽介 ${ }^{1}$ 、原 田真之資 ${ }^{1}$ 、高嶋伸宏 ${ }^{1}$ 宮井博隆 ${ }^{1}$ 、山本 稔 ${ }^{1}$ 、清水保延 ${ }^{1}$ 、田中 守嗣1、早川哲史 ${ }^{2}$

症例は50代女性、子宮癌検診の超音波検查にて骨盤内腫瘤を指摘 された。MRIで仙骨前面の後腹膜に約 $3 \mathrm{~cm}$ の囊胞性腫瘤を認め た。無症状であったが確定診断のためにも手術を希望された。腹 腔鏡下に直腸を授動、腫瘤に入り込む神経束を確認して切離し、 被膜に包まれた状態で腫瘤を摘出した。神経症状等の合併症なく 術後 5 日目に退院となった。病理は紡鍾形細胞の増殖と核の柵状 配列を認め、S-100蛋白 (+)、MIB- 1 標識率（3％) で、良性 神経鞘腫と診断した。今回我々は腹垫鏡下に切除した後腹膜神経 鞘腫の 1 例を経験したので若干の文献的考察を加え報告する。

B25傍神経節腫との鑑別が困難であった後腹膜 Schwannoma $の$ 一例

JA 愛知厚生連豊田厚生病院外科

今村由人、桐山宗泰、久留宮康浩、水野敬輔、世古口英、菅原 元、 河合清貴、鳥居直矢、蟹江恭和、佐久間政宜、稲田亘佑、関本晃 裕、竹内健司

症例は67歳、女性。既往は無く血圧も正常範囲内であった。心雑 音の精查目的に施行した心臓超音波検查で下大静脈背側に $35 \times$ $26 \mathrm{~mm}$ の腫瘍を指摘された。腹部CT検査では、肝下大静脈背側 に境界明瞭な低濃度腫瘍を認めた。MIBG シンチグラフィ検查で は、病変に一致して結節様の集積光進を認めた。畜尿尿中ノルア ドレナリン、ドーパミンは高值を示したが基準值の 3 倍未満であ った。診断基準は満たさなかったものの、傍神経節腫の診断で手 術を施行した。腫瘍の下大静脈への浸潤は認めず、術中に腫瘍に 触れても血圧の変動は認めなかった。被膜の損傷なく腫瘍摘出可 能であった。病理診断はSchwannomaであった。
B26腺癌および神経内分泌腫瘍成分を伴った成人仙尾部奇 形腫の 1 例

愛知県がんセンター中央病院消化器外科

沼田佳久、小森康司、木下敬史、大城泰平、伊藤誠二、安部哲也、 千田嘉毅、三澤一成、伊藤友一、植村則久、夏目誠治、檜垣栄治、 清水泰博

症例は59歳女性。胆石症の術前検查で骨盤内腫瘍を認め紹介受診 となった。精查より開大した仙骨前孔に嵌入する境界明瞭な囊胞 性病変と、その前方に石灰化を伴う充実病変を認めた。仙骨奇形 等を認め、Currarino 3 徵の合併奇形を背景とした悪性疾患とし て手術を施行した。腫瘍に隣接した直腸壁と仙骨前孔からの剥離 は可能で、合併切除することなく腫瘍を摘出した。術後は排尿障 害を認めたが軽快退院となった。病理では仙尾部奇形腫に合併し た腺癌挹よびNETの診断となった。成人仙尾部奇形腫は非常に 稀な疾患であるが本症例はさらに腺癌と NETを伴う稀少な症例 であった。若干の文献的考察を加え報告する。

B27 腹腔鏡下に切除した小網、後腹膜由来のVenous Hemangioma 91 例

大垣市民病院外科

大屋勇人、金岡祐次、原田 徽、亀井桂太郎、前田敦行、高山祐 一、深見保之、高橋崇真、宇治誠人、川勝章司、三品拓也、伊藤 喜介、吉川晃士朗、岡本和浩、田中祐介、手嶋浩也 症例は53歳女性。2 年前の検診で指摘された腹腅内囊胞が増大傾 向となり当院へ紹介となる。自覚症状はなく、身体、血液生化学 所見にも異常を認めない。造影 CTで、胃頭腹側と肝右葉下角付 近に境界明瞭で内部均一な囊胞性病変を認め、腹腔鏡下に切除を 行った。術中所見では小網内に $9.5 \times 6.0 \mathrm{~cm}$ 、右後腹膜に $3.0 \times$ $1.0 \mathrm{~cm}$ の囊胞が見られ、周囲臟器との癒着はない。摘出標本は、 肉眼的には多房性囊胞で内部は淡黄色漿液性であった。病理組織 学的には不規則に拡張し癒合した血管からなる病変であり、肥厚 した血管平滑筋層が見られ、Venous Hemangioma と診断した。 腹坨鏡下に低侵襲に摘出しえた、小網と後腹膜に発生したVenous Hemangiomaを経験したので報告する。

\section{B28 腹胿鏡下に切除した小網平滑筋腫の 1 例}

八千代病院外科

川合 毅、圭野泰司、小林一郎、松原秀雄、金子博和、莱原聖実、 山本龍生、二村雄介、花澤隆明、弥政晋輔

消化管平滑筋腫の多くは胃、小腸に発生するが、小網に発生する ことは稀である。症例は56歳、女性。既往なし。検診USで膵体 尾部のマスを指摘され、精查加療のために紹介された。CTで均 一に濃染される辺縁整で境界明瞭な $3 \mathrm{~cm}$ 大の腫瘤を認めた。 MRIでT 2 低信号、内部に点状高信号を認めた。胃や膵臓との連 続性は明らかでなかった。診断も兼ねて腹腔鏡下に切除した。小 網内に表面平滑で可動性良好な腫瘍を認め、摘出した。病理診断 は平滑筋腫。経過良好で術後 5 日目に退院した。小網平滑筋腫を 術前に診断することは難しく、腹䏶内にマスを認めた場合、本疾 患も鑑別に挙げるべきで、腹腔鏡手術は低侵襲であり、診断治療 に有用と示唆された。

B29 胃癌術後に輸入脚症候群を発症した 1 例

三重北医療センターいなべ総合病院外科

杉田三郎、岡田祐二、友田佳介、角田直樹、石川雅一 症例は70歳男性、平成21年に胃癌に対して、胃全摘術、Roux- 
en-Y 再建術を施行、再発なく経過していた。平成30年 3 月 17 日 の昼食後より嘔吐・腹痛が出現し救急外来受診した。上腹部に強 い圧痛を認め腹部は板状硬であった。腹部 CT 検查ではY 脚吻合 部の十二指腸側で閉塞しており、腸間膜の浮腫が出現、肝内胆管 も拡張、膵管も拡張しており、膵周囲の液体貯留も認めた。輸入 脚症候群と診断し緊急手術を行った。Y脚の吻合部のやや十二指 腸寄りの部分で、策状物により輸入脚の小腸が絞扼されていたた めこれを可及的に切離した。開腹直後は輸入脚の小腸は色調不良 であったが、絞扼解除後は色調も改善が見られたため腸切除は行 わなかった。術後経過は良好で術後 8 日目に退院となった。若干 の文献的考察を加え報告する。 